\title{
ANALISIS YURIDIS PENGAMBILALIHAN SAHAM PT PRIMA TOP BOGA OLEH PT NIPPON INDOSARI CORPINDO, TBK DARI PERPEKTIF UNDANG-UNDANG NOMOR 5 TAHUN 1999 \\ (Studi Kasus Putusan Komisi Pengawas Persaingan Usaha Nomor: 07/KPPU- M/2018)
}

\author{
Suradiyanto \\ suradiyanto@gmail.com \\ Fakultas Hukum Universitas Mulawarman Samarinda \\ Dinny Wirawan Pratiwie \\ dinipratiwie@gmail.com \\ Fakultas Hukum Universitas Widya Gama Mahakam Samarinda
}

\begin{abstract}
The purpose of this study is to review and analyze the legal consequences of acquisitions made on limited liability companies; and based on theconsiderations used by KPPU to determine that PT Nippon Indosari Corpindo, Tbk. Has violated Law Number 5 of 1999.

This research is normative legal research. Secondary data collection in library research is done by studying documents. The data analysis method used in this study is descriptive and analyzed qualitatively.

The results of this study are: (1) Acquisition or Acquisition of Limited Liability Companies can also provide legal consequences affecting the Limited Liability Company. The legal consequences referred to in the Limited Liability Company are the legal consequences both institutionally, namely shareholders, employees, and third parties, as well as the legal consequences of certain parties, especially to third parties or creditors from the acquired limited liability company. In practice that has happened so far, the status of creditors' receivables in a limited liability company that has been acquired is the responsibility of the new Shareholders; and (2) In the reading of the decision it was also explained that the reported party had acquired / taken over shares of PT Prima Top Boga on January 24, 2018, amounting to 32,051 shares (issuance of new shares) taken over by adding capital worth Rp31,499,722,800 , 00 (thirty one billion four hundred ninety nine million seven hundred twenty thousand eight hundred rupiahs) by Pt Nippon Indosari Corpindo, Tbk. After a long process, through the Merger Directorate, it was conveyed that based on the calculation of calendar days, notices of the takeover of shares of the PT Prima Top Boga company should be notified to the Commission no later than March 23, 2018. However, the reported report took place on March 29, 2018.In accordance with PP No. 57 of 2010 that the reported party is obliged to notify the Commission of the acquisition of shares no later than 30 (thirty) working calendar days from the date the juridically effective Business Entity, Business Entity Consolidation or Takeover of Company Shares are effective.
\end{abstract}

Keywords: Stock Takeover, KPPU Decision Number 07 / KPPU-M / 2018

\section{PENDAHULUAN}

\section{A. Latar Belakang}

Menurut Molengraff, perusahaan adalah keseluruhan perbuatan yang dilakukan secaraterus-menerus bertindak keluar untuk memperoleh penghasilan dengan memperniagakanatau menyerahkan barang-barang atau mengadakan perjanjian-perjanjian 
perniagaan. ${ }^{1} \quad$ Dalam perkembangannya keberadaan PT (Perseroan Terbatas) mulai mendominasi bentuk perusahaan yang lain, sehingga menimbulkan persaingan yang berat antara PT (Perseroan Terbatas) satu dengan PT (Perseroan Terbatas) yang lainnya. Dalam setiap persaingan sudah tentu ada pihak yang kalah dan menang, dimana faktor yangmenyebabkan suatu PT (Perseroan Terbatas) mengalami penurunan daya saing adalahkurangnya eksistensi dan kualitas dari barang atau jasa yang diperdagangkan oleh PTtersebut. Sehingga pihak PT tersebut harus melakukan perombakan atau restrukturisasi dan salah satunya dengan cara akuisisi atau pengambil alihan terhadap saham perusahaannya,guna mempertahankan eksistensi dari PT yang bersangkutan. Dengan dilakukannyapengambil alihan perusahaan atau akuisisi, tentunya akan menimbulkan akibat hukumtertentu terhadap pihak PT yang mengambil alih maupun yang diambil alih.

Membahas isu persaingan usaha rasanya tak lengkap tanpa merger, konsolidasi dan akuisisi. Merger, konsolidasi dan akuisisi kerap berpengaruh terhadap persaingan yang terjadi dalam suatu pasar. Hal ini dikarenakan merger, konsolidasi dan akuisisi mudah menyimpangi larangan praktek monopoli dan persaingan usaha tidak sehat yang diakibatkan oleh perjanjian maupun kegiatan yang diatur dalam UndangUndang Nomor 5 Tahun 1999 tentang Larangan Praktek Monopoli dan Persaingan Usaha Tidak Sehat (UU Anti Monopoli). ${ }^{2}$

Merger, konsolidasi dan akuisisi dapat menjadi alat yang sah dan tidak sah bagi pelaku usaha untuk menyingkirkan pesaingnya, oleh karena itu meski dibenarkan undang-undang merger, konsolidasi dan akuisisi akan menjadi legal manakala merger, konsolidasi dan akuisisi

\footnotetext{
${ }^{1}$ Janus Sidabalok, 2012, Hukum PerusahaanAnalisis Terhadap Pengaturan Peran Perusahaan dalam Pembangunan Ekonomi Nasional di Indonesia, Nuasa Aulia, Bandung, hlm. 3

2 Ridwan Khairandy, 2009, Perseroan Terbatas: Doktrin, Peraturan Perundang-undangan dan Yurisprudensi, Total Media, Yogyakarta, hlm. 279
}

itu berdampak positif bagi persaingan usaha dan kepentingan umum. ${ }^{3}$ Adapun lembaga yang berwenang melakukan kontrol atas merger, konsolidasi dan akuisisi tersebut adalah Komisi Pengawas Persaingan Usaha (KPPU).

KPPU adalah lembaga yang tepat untuk melakukan kontrol atas merger. Sebagai otoritas persaingan usaha, KPPU akan menilai merger baik dari aspek prosedural maupun materiil. Merger Review Guidelines (MRG) menurutnya sudah banyak dilakukan oleh negara lain, yang menggunakan sistem pre-notifikasi. Pelaku usaha memberitahu otoritas persaingan tentang rencana merger dan otoritas itu akan menilai dan mengeluarkan pendapat, apakah rencana merger itu dapat diteruskan tanpa syarat atau dengan syarat atau tak dapat diteruskan. ${ }^{4}$

Indonesia sendiri menggunakan sistem yang kedua, karena Pasal 29 Undang-Undang Nomor 5 Tahun 1999 tentang Larangan Praktek Monopoli dan Persaingan Usaha Tidak Sehat tegas menyatakan pelaku usaha wajib untuk melaporkan terjadinya merger selambatnya 30 hari sejak transaksi. Sedangkan Pasal 28 - pasal lainnya tentang merger - hanya menyatakan pelaku usaha yang hendak melakukan merger wajib untuk memastikan merger tidak akan mengakibatkan persaingan usaha tidak sehat.

Pasal 28 maupun Pasal 29 belum dapat diimplementasikan, dikarenakan kedua beleid itu baru dapat diterapkan jika sudah ada Peraturan Pemerintah yang disyaratkan dalam Pasal 28 ayat (3) dan Pasal 29 ayat (2) Undang-Undang Nomor 5 Tahun 1999 tentang Larangan Praktek Monopoli dan Persaingan Usaha Tidak Sehat, oleh karena itu larangan tersebut

3 Gunawan Widjaja, 1999, “Beberapa hal yang perlu diperhatikan oleh Usaha Farmasi dalam Praktek Pelaksanaan Undang-Undang No. 5 Tahun 1999 tentang Larangan Praktek Monopoli dan Persaingan Usaha Tidak Sehat (Antisipasi Kasus Praktek Monopoli dan Litigasi)", Makalah pada Seminar Nasional "Dampak UU Anti Monopoli dan UU Perlindungan Konsumen terhadap Usaha Farmasi di Indonesia, Jakarta, GP Farmasi, hlm. 4 ${ }^{4}$ Ibid, hlm. 5 
belum dapat dilaksanakan karena masih berupa hukum yang belum sempurna. ${ }^{5}$

Pengambilalihan adalah perbuatan hukum yang dilakukan oleh badan hukum atau orang perseorangan untuk megambil alih saham perseroan, yang mengakibatkan beralihnya pengendalian atas perseroan tersebut (Pasal 1 Angka 11 Undang Undang Nomor 40 Tahun 2007 Tentang Perseroan Terbatas (UU No. 40 tahun 2007). Pengambilalihan dilakukan dengan cara pengambilalihan saham yang telah dikeluarkan dan atau akan dikeluarkan oleh perseroan melalui direksi perseroan atau langsung dari pemegang saham (Pasal 125 UU No. 40 Tahun 2007). Secara yuridis cara yang ditempuh untuk mengambil alih suatu perusahaan adalah dengan membeli saham-saham baik sebagian atau seluruhnya dari perusahaan tersebut. ${ }^{6}$

Pengambilalihan perusahaan atau akuisisi dapat dilakukan secara internal atau eksternal, akuisisi internal adalah akuisisi terhadap perusahaan dalam kelompok sendiri, sedangkan akuisisi eksternal adalah akuisisi terhadap perusahaan diluar kelompok atau perusahaan dari kelompok lain. ${ }^{7}$ Perusahaan pengakuisisi biasanya perusahaan besar yang memiliki dana yang kuat, manajemen yang baik, dan jaringan yang luas, serta terkelompok dalam konglomerasi. Akuisisi dapat terjadi secara terpaksa (unfriendly takeover/hostile takeover) dan sukarela/ramah (friendly takeover), yang dimaksud dengan akuisisi secara terpaksa atau (unfriendly takeover/hostile takeover) adalah perusahaan kecil yang sulit berkembang terakuisisi oleh perusahaan yang lebih besar dan tergolong perusahaan konglomerasi. Sedangkan akuisisi sukarela/ramah (friendly takeover) adalah perusahaan kecil yang memang ingin diakuisisi oleh

5 Syamsul Maarif, 2008, Merger, Konsolidasi, Akuisisi dan Pemisahan PT Menurut UU No. 40 Tahun 2007 dan Hubungannya Dengan Hukum Persaingan, dalam Jurnal Hukum Bisnis, Vol. 27 No. 1 Tahun 2008, hlm. 41

6 Abdul .R. Saliman, 2005, Hukum Bisnis untuk Perusahaan, Kencana Prenadamedia Group, Jakarta, hlm. 112

${ }^{7}$ Ibid , hlm. 113 perusahaan konglomerasi tersebut. ${ }^{8}$ Dalam pengambilalihan perusahaan atau akuisisi terdapat beberapa kelebihan yaitu, perusahaan masih menggunakan nama lama dan tidak memerlukan surat izin untuk usaha baru, sedangkan kekurangan dari pengambilalihan perusahaan atau akuisisi yaitu, mudah terjadi duplikasi atau pemborosan dan kepemilikan perusahaan berubah. ${ }^{9}$ Kepentinganyang perlu diperhatikan dalam pengambilalihan perusahaan atau akuisisi yaitu, perseroan pemegang saham minoritas, karyawan perseroan, kreditor dan mitra usaha lainnya dari perseroan, masyarakat dan persaingan sehat dalam melakukan usaha ${ }^{10}$.

Transaksi merger di Indonesia juga sering dilakukan oleh banyak perusahaan. Sebut saja misalnya merger antar beberapa bank milik pemerintah yang sekarang menjadi Bank Mandiri. Beberapa bank swasta juga kerap melakukan merger, misalnya merger antar bank swasta yang sekarang menjadi Bank Permata. Selain di sektor perbankan, sejak beberapa tahun yang lalu transaksi merger juga terjadi di sektor ritel misalnya Carrefour Hypermarket dengan Continental Hypermarket. ${ }^{11}$ Dengan adanya merger tersebut maka PT Carrefour Indonesia telah menguasai pangsa pasar bisnis ritel di Indonesia dan hal ini bertentangan dengan Undang-Undang Nomor 5 Tahun 1999 tentang Larangan Praktek Monopoli dan Persaingan Usaha Tidak Sehat. ${ }^{12}$

Akuisisi antar perusahaan nasional dan perusahaan milik asing juga telah terjadi baik secara keseluruhan maupun sebagian saham, seperti pengambilalihan saham PT Indosat dan PT Telkomsel oleh Temasek Group, pengambilalihan saham Bank BCA dan pengambilalihan saham PT Alfa Retalindo Tbk oleh PT Carrefour dan lain-lain. PT Carrefour Indonesia resmi membeli 75\% saham PT Alfa Retailindo dengan nilai pembelian saham sebesar 49,3 juta euro atau setara dengan Rp. 674 milyar.

\footnotetext{
${ }^{8}$ Ibid

${ }^{9}$ Ibid, hlm. 114

10 H. Zaeni Asyhadie dan Budi Sutrisno, op.cit, hlm. 110

${ }^{11}$ Ibid

${ }^{12}$ Ibid
} 
Dengan melakukan akuisisi tersebut, PT Carrefour menjadi perusahaan ritel terdepan di Indonesia dan berdasarkan data retail Asia tahun 2007, Carrefour Indonesia per tahun 2006 memiliki omzet hingga Rp. 7.2 trilyun dan menjadi pemimpin pasar ritel Indonesia, sedangkan PT Alfa memiliki omzet Rp. 1,9 trilyun menduduki peringkat $10 .{ }^{13}$

Komisi Pengawas Persaingan Usaha (KPPU) memutuskan untuk mendenda PT Nippon Indosari Corpindo Tbk (ROTI) sebesar Rp2,8 miliar. Denda tersebut dijatuhi karena ROTI terlambat melakukan pelaporan akusisi saham perusahaan roti dengan merek BonChef, PT Prima Top Boga. Pemilik merek Sari Roti ini melanggar Pasal 29 Undang-Undang Nomor 5 Tahun 1999 jo dan Pasal 5 Peraturan Pemerintah Nomor 57 Tahun 2010.

Dalam keterangan resmi KPPU disebutkan bahwa Ketua Majelis Komisi, Ukay Karyadi, serta Anggota Komisi Guntur S Saragih dan Dinni Melanie memutuskan terlapor, PT Nippon Indosari Corpindo Tbk untuk membayar denda sebesar Rp2,8 miliar yang harus disetor ke Kas Negara sebagai setoran pendapatan denda pelanggaran di bidang persaingan usaha Satuan Kerja Komisi Pengawas Persaingan Usaha.

Dalam pembacaan putusan, juga dijelaskan bahwa ROTI melakukan akuisisi pengambilalihan saham terhadap PT Prima Top Boga pada 24 Januari 2018, sebesar 32.051 lembar saham melalui penerbitan saham baru yang diambilalih dengan cara penambahan modal senilai Rp31,49 miliar.

Setelah proses yang panjang, melalui Direktorat Merger, disampaikan bahwa berdasarkan penghitungan hari kalender, pemberitahuan pengambilalihan saham perusahaan PT Prima Top Boga seharusnya diberitahukan kepada Komisi paling lambat pada 23 Maret 2018. Namun, terlapor melaporkan pengambilalihan saham pada 29 Maret 2018.
Sesuai dengan Peraturan Pemerintah Nomor 57 Tahun 2010, terlapor wajib memberitahukan kepada Komisi mengenai pengambilalihan saham selambat-lambatnya 30 (tiga puluh) hari kalender.

\section{B. Rumusan Masalah}

Berdasarkan uraian dalam latar belakang masalah tersebut di atas, maka permasalahan dalam penelitian ini dirumuskan sebagai berikut:

a. Bagaimana akibat hukum akuisisi yang dilakukan pada perseroan terbatas?

b. Dasar pertimbangan apakah yang dipergunakan oleh KPPU untuk menentukan bahwa PT Nippon Indosari Corpindo, Tbk. Telah melanggar Undang-Undang Nomor 5 Tahun 1999?

\section{Tujuan dan Manfaat Penelitian}

Adapun tujuan dari penelitian ini adalah untuk mengkaji dan menganalisis akibat hukum akuisisi yang dilakukan pada perseroan terbatas, dan untuk menganalisis dan mengkaji Dasar pertimbangan yang dipergunakan oleh KPPU untuk menentukan bahwa PT Nippon Indosari Corpindo, Tbk. Telah melanggar UndangUndang Nomor 5 Tahun 1999.

Adapun penelitian ini diharapkan bermanfaat sebagai sumbangan pemikiran dalam pengembangan ilmu hukum khususnya tentang hukum perusahaan, Mampu memberikan sumbangan pemikiran dalam pengembangan ilmu hukum perusahaan khususnya tentang analisis yuridis pengambilalihan saham perusahaan dari perspektif Undang-Undang Nomor 5 Tahun 1999.

Penelitian ini juga merupakan rekomendasi bagi penelitian lebih lanjut tentang analisis yuridis pengambilalihan saham perusahaan dari sudut pandang yang berbeda 


\section{METODE PENELITIAN}

Penelitian ini merupakan penelitian hukum normatif, yaitu penelitian yang dilakukan dengan mendasarkan pada data kepustakaan sebagai data utamanya yang merupakan data sekunder dan berupa bahan-bahan hukum.

Data yang dibutuhkan dalam penelitian ini adalah data sekunder, yaitu data yang diperoleh dari penelitian kepustakaan yang berupa bahan-bahan hukum yang terdiri dari: ${ }^{14}$

1) Bahan Hukum Primer, yaitu bahan hukum yang bersifat mengikat yang terdiri dari :

a) Undang-Undang Nomor 1 Tahun 1995 tentang Perseroan Terbatas sebagaimana telah dirubah dengan Undang-Undang Nomor 40 Tahun 2007 tentang Perseroan Terbatas;

b) Undang-Undang Nomor 8 Tahun 1995 tentang Pasar Modal;

c) Undang-Undang Nomor 5 Tahun 1999 tentang Larangan Praktik Monopoli dan Persaingan Usaha Tidak Sehat;

d) Undang-Undang Nomor 30 Tahun 2004 tentang Jabatan Notaris;

e) Peraturan Pemerintah Nomor 27 Tahun 1999 tentang Penggabungan, Peleburan, dan Pengambilalihan Perusahaan;

f) Peraturan Bapepam No. IX.G.1 tentang Penggabungan Usaha atau Peleburan Usaha Perusahaan Publik atau Emiten;

g) Peraturan Bapepam No. IX.E.1 tentang Benturan Kepentingan Transaksi Tertentu;

h) Peraturan Bapepam No. X.K.1 tentang Informasi yang Harus Segera Diumumkan Kepada Publik;

i) Peraturan KPPU Nomor 1 Tahun 2009 tentang Pra-Notifikasi Penggabungan, Peleburan dan Pengambilalihan;

j) Keputusan Ketua Bapepam Nomor Kep-52/PM/1997 tentang
Penggabungan Usaha atau Peleburan Usaha Perusahaan Publik atau Emiten;

k) Keputusan Komisi Pengawas Persaingan Usaha Nomor 09/KPPU-L/2009;

2) Bahan Hukum Sekunder, yaitu bahan hukum yang memberikan petunjuk dan kejelasan terhadap bahan hukum primer, yang terdiri dari buku-buku literatur, makalah, artikel, hasil penelitian, dan karya ilmiah lainnya yang berhubungan dengan penelitian ini.

3) Bahan Hukum Tertier, yaitu yaitu bahan hukum yang memberi petunjuk maupun penjelasan terhadap bahan hukum primer dan bahan hukum sekunder, yang terdiri dari :

a) Kamus Hukum

b) Kamus Inggris - Indonesia

c) Ensiklopedia

Pengumpulan data sekunder dalam penelitian kepustakaan ini dilakukan dengan cara studi dokumen, yaitu mempelajari, mengkaji dan menelaah bahan-bahan hukum baik yang berupa bahan hukum hukum primer, bahan hukum sekunder dan bahan hukum tertier.

Metode pendekatan yang dipergunakan dalam penelitian ini adalah yuridis normatif, yaitu menganalisis permasalahan dari sudut pandang/menurut ketentuan hukum/perundang-undangan yang berlaku.

Metode analisis data yang dipergunakan dalam penelitian ini adalah deskriptif dan dianalisis secara kualitatif dengan langkah-langkah sebagai berikut:

1) Data sekunder yang diperoleh dari penelitian diklasifikasikan sesuai dengan permasalahan dalam penelitian.

2) Hasil klasifikasi selanjutnya disistematisasikan

3) Data yang telah disistematisasikan kemudian dianalisis untuk dijadikan dasar dalam mengambil kesimpulan.

${ }^{14}$ Soerjono Soekanto dan Sri Mamudji, 2003, Penelitian Hukum Normatif, Suatu Tinjauan Singkat, PT. Raja Grafindo Persada, Jakarta, hlm. 13 


\section{PEMBAHASAN}

\section{Pengertian dan Dasar Hukum Larangan Praktik Monopoli dan Persaingan Usaha Tidak Sehat}

Menurut Undang-Undang Nomor 5 Tahun 1999, monopoli didefinisikan sebagai suatu bentuk penguasan atas produksi dan atau pemasarang barang dan atau atas penggunaan jasa tertentu oleh satu pelaku atau satu kelompok pelaku usaha. Dalam Black's Law Dictionary, monopoli diartikan sebagai a privilege veted in one or more persons or companies, consisting in the exclusive right (or power) to carry on a particular business or trade, manufacture a particular article, or control the sale of the whole supply of a particular commodity. ${ }^{15}$ Berbeda dari definisi yang diberikan dalam undang-undang yang secara langsung menunjuk pada penguasaan pasar, dalam Black's Law Dictionary penekanan lebh diberikan pada adanya suatu hak istimewa (privilege) yang menghapuskan persaingan bebas, yang tentu pada akhirnya juga akan menciptakan penguasaan pasar. ${ }^{16}$

Selanjutnya dalam Black's Law Dictionary $^{17}$ dikatakan Monopoly as prohibited by Section 2 of the Sherman Antitrust act, has two elements:

a. possession of monopoly power in relevant market;

b. willful acquisition or maintenance of that power.

Dalam hal ini jelas bahwa Monopoli yang dilarang oleh Section 2 dari Sherman Act adalah monopoli yang bertujuan untuk menghilangkan kemampuan untuk melakukan persaingan dan atau untuk tetap mempertahankannya.

Hal ini mmberikan konsekuensi dimungkinkan dan diperkenankan monopoli yang terjadi secara alamiah, tanpa adanya kehendak drai pelaku usaha tersebut untuk melakukan monopoli. Section 2 dari Sherman Act memang lebih menekankan pada proses terjadinya monopolitisasi dan

15 Ahmad Yani dan Gunawan Widjaja, 1999, Seri Hukum Bisnis, Anti Monopoli, Rajawali Press, Jakarta, hlm. 16

${ }^{16} \mathrm{Ibid}$

${ }^{17} \mathrm{Ibid}$, hlm. 17 bukan pada monopoli yang ada. Ada beberapa argument yang dapat dikemukakan sehubungan dengan proses terjadinya monopoli secara alamiah.

Selain definisi dari monopoli, dalam Undang-Undang Nomor 5 Tahun 1999 juga diberikan pengertian dari praktek monopoli, yaitu suatu pemusatan kekuatan ekonomi oleh satu atau lebih pelaku usaha yang mengakibatkan dikuasainya produksi dan atau pemasaran atas barang dan atau jasa tertentu sehingga menimbulkan persaingan usaha tidak sehat dan dapat merugikan kepentingan umum.

Dari definisi yang diberikan di atas dapat diketahui bahwa pada dasarnya ada 4 hal penting yang dapat dikemukakan tentang praktek monopoli ini yaitu: ${ }^{18}$

a. adanya pemusatan kekuatan ekonomi;

b. pemusatan kekuatan tersebut berada pada satu atau lebih pelaku usaha ekonomi;

c. pemusatan kekuatan ekonomi tersebut menimbulkan persaingan usaha tidak sehat; dan

d. pemusatan kekuatan ekonomi tersebut merugikan kepentingan umum.

Dari pengertian yang diberikan di atas jelas dapat dilihat bahwa salah satu prasyarat pokok dapat dikatakan telah terjadi suatu pemusatan kekuatan ekonomi adalah telah terjadinya penguasaan nyata dari suatu pasar bersangkutan sehingga harga dari barang atau jasa yang diperdagangkan tidak lagi mengikuti hukum ekonomi mengenai permintaan dan penjualan, melainkan semata-mata ditentukan oleh satu atau lebih pelaku ekonomi yang menguasai pasar tersebut.

\section{Akibat Hukum Dari Akuisisi Pada Perseroan Terbatas \\ Pengambilalihan atau Akuisisi Pada} Perseroan Terbatas ternyata juga dapat memberikan akibat hukum yang mempengaruhi Perseroan Terbatas. Akibat hukum yang dimaksud dalam Perseroan Terbatas tersebut adalah Akibat hukum baik secara kelembagaan yaitu pemegang Saham, karyawan, maupun pihak ketiga,

\footnotetext{
${ }^{18}$ Ibid
} 
maupun akibat hukum terhadap pihak-pihak tertentu, terutama adalah terhadap pihak ketiga atau kreditur dari perseroan terbatas yang diakuisisi. Dalam praktek yang terjadi selama ini, status piutang kreditur pada perseroan terbatas yang di akuisisi menjadi tanggung jawab pemegang Saham yang baru.

\section{Dasar Pertimbangan yang Dipergunakan oleh KPPU untuk Menentukan bahwa PT Nippon Indosari Corpindo, Tbk. Telah Melanggar Undang-Undang Nomor 5 Tahun 1999}

Berikut disajikan dasar pertimbangan

Komisi Pengawas Persaingan Usaha (KPPU) dalam memutus perkara akuisisi saham PT Prima Top Boga yang dilakukan oleh PT Nippon Indosari Corpindo, Tbk. dengan uraian sebagai berikut:

Majelis Komisi telah mempelajari Tanggapan Terlapor atasLaporan Keterlambatan Pemberitahuan pada Sidang Majelis Komisi II Pemeriksaan Pendahuluan tanggal 29 Oktober 2018. Majelis Komisi juga mempelajari Kesimpulan Terlapor pada Sidang Majelis Komisi Pemeriksaan Lanjutan tanggal 19 November 2018.

Tanggapan dan Kesimpulan Terlapor menyatakan PT Prima Top Boga sebagai Perusahaan Modal Asing (PMA) walaupun telah memperoleh persetujuan Menteri Hukum dan HAM, wajib untuk mendapatkan persetujuan lebih dahuludari BKPM atas adanya perubahan pendaftaran PMA terkait perubahan susunan pemegang sahamnya. Tanpa Persetujuan dari BKPM tersebut, pengambilalihan saham PT Prima Top Boga oleh Terlapor tidak dapat dinyatakan telah berlaku efektif secara yuridis.

PT Prima Top Boga telah mendapatkan persetujuan dari BKPM sebagaimana terdapat dalam surat Pendaftaran PMA Nomor 469/1/PI_PB/PMA/2018 pada tanggal 1 Maret 2018. Pendaftaran Penanaman Modal tersebut merupakan bagian yang tidak terpisahkan atas izin prinsip Nomor 227/1/IP/PMA/20 14 tanggal 27 Januari
2014 jo. Peru bahan terakhir nomor 3758/ 1/IP-PB/PMA/2017 tanggal 17 Oktober 2017.

Majelis Komisi menilai berdasarkan fakta persidangan dan keterangan Ahli Hukum Persaingan Usaha (Dr. Anita Afri ana, S.H., M.H.) menyatakan perihal Pasal 26 UU Nomor 40 Tahun 2007 yang mengatur bahwa tanggal efektif yuridis, yaitu ketika mendapat persetujuan dari Menteri Hukum dan HAM dan ditetapkan dalam ketetapan persetujuan Menteri Hukum dan HAM atau ketika perubahan Anggaran Dasar itu diberitahukan kepada Menteri Hukum dan HAM.

Majelis Komisi menilai berdasarkan fakta persidangan dan keterangan Ahli BKPM (Dr. Riyatno, S.H., LL.M.) menyatakan Peraturan BKPM tidak mengatur efektif yuridis, karena tugas BKPM memberikan pelayanan perizinan PMA. BKPM tidak mengatur terkait efekt if yuridis akuisisi;

Bahwa Majelis Komisi menilai efektif yuridis dalam UU Nomor 40 Tahun 2007 dinyatakan dalam Pasal 23 ayat 1 : "perubahan anggaran dasar sebagaimana dimaksud dalam Pasal 21 ayat (2) mulai berlaku sejak tanggal diterbitkannya Keputusan Menteri mengenai persetujuan perubahan anggaran dasar." Pasal 23 ayat (2): "perubahan anggaran dasar sebagaimana dimaksud dalam Pasal 21 ayat (3), mulai berlaku sejak tanggal diterbitkannya surat penerimaan pemberitahuan perubahan anggaran dasar oleh Menteri." Pasal 26 UU Nomor 40 Tahun 2007: "perubahan anggaran dasar yang dilakukan dalam rangka penggabungan/pengambilalihan berlaku sejak tanggal: a. Persetujuan Menteri; b. Kemudian ditetapkan dalam Persetujuan Menteri; atau c. Pemberitahuan perubahan anggaran dasar diterima Menteri, atau tanggal kemudian yang ditetapkan dalam akta penggabungan atau akta pengambilalihan".

Bahwa Majelis Komisi menilai kewenangan BKPM tidak berkaitan dengan pengambilalihan saham (akuisisi) perusahaan melainkan teknis mengenai tata cara perizinan dan fasilitas penanaman modal bagi PMA. Kewenangan BKPM 
terkait dengan PMA bertujuan untuk pencatatan modal di BKPM. Sementara untuk proses pengambilalihan saham berada pada Direktorat Jenderal Administrasi Hukum Umum, Kementerian Hukum dan HAM dan tidak melibatkan BKPM. Tanggal efektif yuridis pengambilalihan saham (akuisisi) hanya diatur dalam UU Nomor 40 Tahun 2007 dan PP Nomor 57 Tahun 2010, dan bukan pada Peraturan BKPM;

Bahwa dengan demikian, Majelis Komisi menilai bahwa tanggal efektif yuridis ditentukan dari SK perubahan anggaran dasar PT Prima Top Boga pada tanggal 9 Februari 2018 Nomor AHU./AH.01.03-0061708 yang dikeluarkan oleh Kementerian Hukum dan HAM. Pada tanggal 29 Maret 2018 Terlapor menyampaikan pemberitahuan pengambilalihan saham (akuisisi) secara resmi kepada Komisi. Majelis Komisi menilai berdasarkan PPNomor 57 Tahun 2010 menyatakan 30 (tiga puluh) hari kerja sejak tanggal telah berlaku efektif secara yuridis, sehingga batas akhir notifikasi jatuh pada tanggal 23 Maret 2018. Berdasarkan hal tersebut, Majelis Komisi menilai terdapat keterlambatan selama empat (4) hari.

\section{PENUTUP \\ KESMPULAN DAN SARAN}

Berdasarkan hasil analisis dan kajian terhadap Putusan Komisi Pengawas Persaingan Usaha (KPPU) Nomor 07/KPPU-M/2018, maka dapat ditarik kesimpulan yang merupakan jawaban dari permasalahan dalam penelitian ini sebagai berikut:

Pengambilalihan atau Akuisisi Pada Perseroan Terbatas ternyata juga dapat memberikan akibat hukum yang mempengaruhi Perseroan Terbatas. Akibat hukum yang dimaksud dalam Perseroan Terbatas tersebut adalah Akibat hukum baik secara kelembagaan yaitu pemegang Saham, karyawan, maupun pihak ketiga, maupun akibat hukum terhadap pihak-pihak tertentu, terutama adalah terhadap pihak ketiga atau kreditur dari perseroan terbatas yang diakuisisi. Dalam praktek yang terjadi selama ini, status piutang kreditur pada perseroan terbatas yang di akuisisi menjadi tanggung jawab pemegang Saham yang baru.

Setelah adanya proses yang panjang, melalui Direktorat Merger disampaikan bahwa berdasarkan penghitungan hari kalender, pemberitahuan pengambilalihan saham perusahaan PT Prima Top Boga seharusnya diberitahukan kepada Komisi paling lambat pada 23 Maret 2018. Namun terlapor melaporkan pengambilalihan saham pada 29 Maret 2018.

Sesuai dengan PP No.57 Tahun 2010 bahwa terlapor wajib memberitahukan kepada Komisi mengenai pengambilalihan saham Selambat-Lambatnya 30 (tiga puluh) hari kalender kerja sejak tanggal telah berlaku efektif secara yuridis Penggabungan Badan Usaha, Peleburan Badan Usaha atau Pengambilalihan Saham Perusahaan.

Adapun saran atau rekomendasi terhadap penelitian ini yaitu Sebagai upaya menghindari terjadinya persaingan usaha tidak sehat dan untuk efektifitas ketentuan mengenai merger baik yang tercantum dalam Undang-Undang Nomor 5 Tahun 1999 maupun Undang-Undang Nomor 40 Tahun 2007, Komisi Pengawas Persaingan Usaha (KPPU) RI telah mengeluarkan peraturan Komisi Pengawas Persaingan Usaha RI Nomor 1 Tahun 2009 tentang Pra-Notifikasi Penggabungan, Peleburan dan Pengambilalihan yang menentukan bahwa bentuk notifikasi/ pemberitahuan merger kepada KPPU dapat berbentuk pranotifikasi dan post-notifikasi.

Dalam rangka harmonisasi dengan standar internasional, dan selama tidak bertentangan dengan ketentuan yang berlaku secara nasional, maka peraturan pelaksanaan mengenai transaksi merger dapat menggunakan sistem dan standar yang telah terbukti efektif di banyak negara untuk mencegah terjadinya transaksi merger yang menimbulkan dampak negatif terhadap persaingan. Sistem tersebut diantaranya adalah digunakannya prenotifikasi. Penerapan sistem ini sangat penting untuk menghindarkan terjadinya pembatalan merger oleh KPPU. Dengan 
sistem pre-notifikasi maka rencana merger besar sebelum diumumkan atau disahkan oleh Menhuk dan HAM atau otoritas sektoral seperti Menteri Keuangan, BI, Bapepam, dan BKPM dinotifikasikan terlebih dahulu ke KPPU untuk mendapatkan penilaian. Selain memberikan kepastian bagi pelaku usaha, sistim prenotifikasi tidak bertentangan dengan Undang-Undang Nomor 5 Tahun 1999.

\section{DAFTAR PUSTAKA}

\section{Buku/Literatur}

Abdul .R. Saliman, 2005, Hukum Bisnis untuk Perusahaan, Kencana Prenadamedia Group, Jakarta

Ahmad Yani dan Gunawan Widjaja, 1999, Seri Hukum Bisnis, Anti Monopoli, Rajawali Press, Jakarta

Janus Sidabalok, 2012, Hukum Perusahaan- Analisis Terhadap Pengaturan Peran Perusahaan dalam Pembangunan Ekonomi Nasional di Indonesia, Nuasa Aulia, Bandung

\section{Perundang-undangan}

Undang-Undang Nomor 1 Tahun 1995 tentang Perseroan Terbatas sebagaimana telah dirubah dengan Undang-Undang Nomor 40 Tahun 2007 tentang Perseroan Terbatas

Undang-Undang Nomor 8 Tahun 1995 tentang Pasar Modal

Undang-Undang Nomor 5 Tahun 1999 tentang Larangan Praktik Monopoli dan Persaingan Usaha Tidak Sehat

Undang-Undang Nomor 30 TAhun 2004 tentang Jabatan Notaris

Peraturan Pemerintah Nomor 27 Tahun 1999 tentang Penggabungan, Peleburan, dan Pengambilalihan Perusahaan
Ridwan Khairandy, 2009, Perseroan Terbatas: Doktrin, Peraturan Perundang-undangan dan Yurisprudensi, Total Media, Yogyakarta

Soerjono Soekanto dan Sri Mamudji, 2003, Penelitian Hukum Normatif, Suatu Tinjauan Singkat, PT. Raja Grafindo Persada, Jakarta

Peraturan BAPEPAM No. IX.G.1 tentang Penggabungan Usaha atau Peleburan Usaha Perusahaan Publik atau Emiten.

Peraturan BAPEPAM No. IX.E.1 tentang Benturan Kepentingan Transaksi Tertentu

Peraturan BAPEPAM No. X.K.1 tentang Informasi Yang Harus Segera Diumumkan Kepada Publik

Peraturan KPPU Nomor 1 Tahun 2009 tentang Pra-Notifikasi Penggabungan, Peleburan dan Pengambilalihan 
Keputusan Ketua BAPEPAM Nomor Kep52/PM/1997 tentang Penggabungan Usaha atau Peleburan Usaha Perusahaan Publik atau Emiten

Keputusan Komisi Pengawas Persaingan Usaha Nomor 09/KPPU-L/2009

\section{Jurnal/Makalah}

Gunawan Widjaja, 1999, "Beberapa hal yang perlu diperhatikan oleh Usaha Farmasi dalam Praktek Pelaksanaan Undang-Undang No. 5 Tahun 1999 tentang Larangan Praktek Monopoli dan Persaingan Usaha Tidak Sehat (Antisipasi Kasus Praktek Monopoli dan Litigasi)", Makalah pada Seminar Nasional "Dampak UU Anti Monopoli dan UU Perlindungan Konsumen terhadap Usaha Farmasi di Indonesia, Jakarta, GP Farmasi

Syamsul Maarif, 2008, Merger, Konsolidasi, Akuisisi dan Pemisahan PT Menurut UU No. 40 Tahun 2007 dan Hubungannya Dengan Hukum Persaingan, dalam Jurnal Hukum Bisnis, Vol. 27 No. 1 Tahun 2008 